\title{
Following the Footprints of Edward S. Curtis: A Tale of the Vanishing Race
}

\author{
Kalina Kukiełko-Rogozińska \\ University of Szczecin \\ Szczecin, Poland
}

DOI: http://dx.doi.org/10.18778/1733-8069.16.2.03

Keywords:

photographs of indigenous peoples, First Nations, Indians of North America, vanishing race, visual sociology

\begin{abstract}
In 2007, Marie Clements, a Canadian playwright, was asked to prepare a play about the cultural history of Canada. She decided to write a play about Edward S. Curtis, the author of an epic series of photographic works titled The North American Indian, published between 1900 and 1930. Clements invited to the project Rita Leistner, a Canadian photographer, who was responsible for the graphic aspect of the play. Her task was to recreate the way taken by Curtis while immortalizing scenes from the life of the indigenous peoples. Both artists took a fascinating journey following the footsteps of Curtis documenting today's presence of the First Nations in the United States and Canada.

This article, based on the project of Clements and Leistner, discusses the ambiguity of the medium of photography, one which 'recreates'the reality and at the same time allows the authors to'create' it. It presents three basic themes: the mission and work of Edward S. Curtis; the play titledThe Edward Curtis Project: A Modern Picture Story by Marie Clements; and the photographs - prepared by Rita Leistner - which were used in play and then published in the book of the same title. The purpose of this text is to present the project of the Canadian authors in the context of visual sociology and anthropology, and to show the potential of photography as a means of building social discourse and creating a narrative of a specific community. It is founded on the assumption that the artistic project in question - based on (both passive and active) participation of the authors in the everyday life of the community presented in it - becomes a source of valuable research material, which can then be subjected to scientific interpretations.
\end{abstract}

KalinaKukiełko-Rogozińska, PhD - adjunct at the Institute of Sociology, University of Szczecin; author of the book titled Między nauka a sztuka. Teoria i praktyka artystyczna w ujęciu Marshalla McLuhana, which was prized in 2016 with the Pierre Savard Award; scientific editor of the first Polish translation of The Gutenberg Galaxy by Marshall McLuhan (2017), which is the book recognized by the Polish Sociological Association as the best translation of the year (2018); Vis- iting Scholar at Concordia University of Edmonton, Canada (2019).

\section{Contact details:}

Uniwersytet Szczeciński, Instytut Socjologii

Wydział Nauk Społecznych

ul. Krakowska 71-79, 71-017 Szczecin

email address: kalina.rogozińska@usz.edu.pl 
There is no document of civilization

which is not at the same time a document of barbarism. Walter Benjamin (1940)

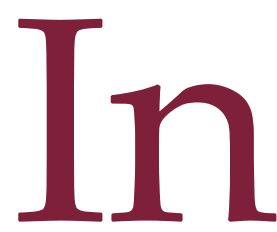

2007, Marie Clements, a playwright, novelist and director of Indian descent, was commissioned by the Presentation House Theatre to prepare a theater play about the cultural history of Canada. She decided to present this topic from the perspective of the indigenous peoples of America, and it was not a random choice. In her analysis of the First Nations' contemporary theater, Ann Huago (2016) states that as a viewer and critic she is indeed "fascinated by the multiple trajectories of meaning and the complex readings that Clements's dramaturgy produces, built by a web of image citations, reflecting and accumulating from scene to scene," and points out that her

interest, however, resides not only in that astounding complexity but also in the political contexts for her work, in all its layers of meaning and images: feminist and indigenous, a liberating and transformative poetics that makes theatre into ceremony not a New Age, let's-all-feel-good-and-dance-in-acircle ceremony but a ceremony of communal power, often women's communal power, that transcends the material limitations placed on her characters in daily life. (p. 270)

The premiere of the commissioned work was intended as the key event of the Cultural Olympiad held in Vancouver three years later. Clements decided to write a play about Edward S. Curtis, the author of an epic series of photographic works titled The North American Indian, published between 1900 and 1930. Curtis, the world-famous American photographer, was involved in documenting the life of Native Americans at the turn of the nineteenth century, when they were considered a dying race. Many of his models called him 'Shadow Catcher.' Today, numerous portraits he authored are perceived more as a reflection of colonial images and fantasies about Amerindians rather than as actual documents of their way of life. However, Clements, who sees Curtis primarily as an artist a photographer with a unique look - notes (2014) that his

portraits are infantilized by his descriptions of them. Many times, he only describes his 'subject' in the most generic manner, as if labeling only for his consumption. Content: man. Where he took it: place. What his subject is wearing rather than their name. [...] Many could say that this was a product of the time, but if time can stand still when looking at great art... it can also stand still when it betrays its own good intention. (no pagination)

Clements invited Rita Leistner, a Canadian photographer, to participate in the project. She was responsible for the visual aspect of the play. Her task was to recreate the way taken by Curtis while immortalizing scenes from the life of the indigenous peoples. Both artists took a fascinating journey following the footsteps of Curtis documenting today's presence of the First Nations in the United States and Canada. This way, the unusual work titled The Edward Curtis Project: A Modern Picture Story was created. The project is an obvious reference to The Indian Picture Opera, presented by Curtis himself in winter of 1911/1912 at The Carnegie Hall in New York: a combination of photographs and slide shows, accompanied by original music composed by Henry Gilbert (Gilbert's compositions were also used in the play by Clements). 
The article herein ${ }^{1}$ discusses the project of Clements and Leistner with an emphasis on the interesting ambiguity of the medium of photography, which 'recreates' the reality and at the same time allows the authors to 'create' it. The described project also addresses various issues that the observers and ethnographers of indigenous North American populations have been struggling with for decades. These include: how to avoid artificial staging while presenting the life of Amerindians; how to cope with unjust assessments of race or sex/gender in the contemporary discourse; what is the status of a witness and what duties it involves; what can and should be done to support the survival of these minorities.

Moreover, the photographic narrative presented by the authors - balancing between an artistic creation, a record of participatory observation, and an unbiased description of the existing data - can be interpreted in the context of visual sociology and anthropology. Photographs by Curtis and Leistner as well as the play by Clements - their supplement (or their attempted explanation) - can be treated as a visual description of a specific, partly historical community. "Visual research in the field of anthropology and sociology can be carried out in many ways. They all involve production, organization, analysis and interpretation of images... The scope of visual research includes a wide range of topics, among others: identification, power relations, type of spatial interactions, corporeality, identity, individual and collective memory" (Jeziorski 2011:11). The question of the 'historical truth' or 'reality' of the characters, the situations and contexts presented in the photographs, as well as the possibility of their interpretation -all remain open.

${ }_{1}^{1}$ The article has been written by courtesy of the Library of the John F. Kennedy Institute Research Grant, Berlin (February-March 2019).

\section{Edward S. Curtis}

Edward Sheriff Curtis began his photographic career at the turn of the nineteenth century. The first picture of an indigenous North American made by him was the portrait of "Princess Angeline," the daughter of the Chief Sealth of Seattle, who became an inspiration of two female characters in the play by Clements. After receiving financial support, he began multi-annual work on preparing photographs for the twenty-volume publication under the working title American Indians. The first volume was issued in 1907, with introduction written by Theodore Roosevelt (1976), who kindly expressed his appreciation for the work and personality of the photographer:

[i]n Mr. Curtis we have both and artist and a trained observer, whose pictures are pictures, not merely photographs; whose work has for more than mere accuracy, because it is truthful. [...] He is a close observer, whose qualities of mind and body fit him to make his observation out in the field, surrounded by the wild life be commemorates. He has lived on intimate terms with many different tribes of the mountains and the plains. He knows them as they hunt, as they travel, as they go about their various avocations on the march and in the camp. He knows their medicine men and sorcerers, their chiefs and warriors, their young men and maidens. (no pagination)

Today the work of Curtis raises questions regarding the 'naturalness' of the presented portraits. The photographer was even accused of staging idealized images of the life of native Americans before the arrival of colonizers from Europe (he reportedly borrowed appropriate 'props' from museums!). Nevertheless, the impact of his opus cannot be overestimated. "These photographs have been, for 
over one hundred years, the international community's main point of access to representations of aboriginal peoples; yet it is a work that, in attempting to capture the image of authentic, pre-contact aboriginal culture, problematizes the limits of representation, where truth becomes merely a perspective" (Nanibush 2011:3). During his lifetime, Curtis took approximately forty thousand pictures, but by no means did he limit himself to the medium of photography. He also tried to document existing manifestations of the life and culture of the Amerindians, which - according to a popular conviction of that time - was to disappear irretrievably. For example, he recorded thousands of wax gramophone cylinders with samples of native speech and songs. He wrote down tribal legends and histories, collected information on traditional cuisine, ways of building houses, settlements, leisure time, as well as religious and funeral ceremonies. He made biographical notes of chieftains of particular tribes - this collection is, in many cases, the only existing record of the lives of tribes which were disappearing or being 'civilized.' As Candy Moulton (2015) states,

[t]he works of Curtis "are unique in many ways and on many levels. First and foremost they are the result of a highly collaborative, cocreative endeavor. Even a superficial inspection reveals the native people were critical participants and co-creators. They were as committed as Curtis to creating this record that would become, in many cases, the only record their descendants would have of what they looked like, who they were and what they believed in. In many of Curtis' finest portraits one sees an intimacy, vulnerability and intensity of involvement on the part of the native participants that simply does not exist in any depth or consistency in the work of any other photographer of the American Indian. (p. 16)
Collecting visual material, which is often the basis of ethnographic research, sometimes necessarily requires some interference in the existing social reality as well as needs "a series of more or less organized interactions in which the researcher, by causing a reaction with his action (his motion, conversation or just presence), it also evokes data then reduced and recoded to other forms" (Dziewit and Pisarek 2016:14-15). Field work is, therefore, a kind of chain of re-coding, translations, and displacements.

Moreover, as Clements and Leistner point out in their project, even the controversial actions of Curtis - staging or reconstructing 'authentic' cultural practices, such as dances and ceremonies - can and should be treated as fully justified strategies serving to preserve cultures of the indigenous Americans, especially in the period when the 'white' state forbade to celebrate them. In one of the scenes in the play by Clements, the protagonist makes a statement (inspired by one of real lectures by Curtis), which can be considered as an excellent summary of his work: As the authors state (2010),

[m]y greatest desire tonight is that each and every person here enter into the spirit of our evening with the Indians. We cannot weight, measure, or judge their culture with our philosophy. From our analytical and materialistic viewpoint theirs is a strange world. Deity is not alone in a world of universal voice, universal spirit. I want to see this beautiful, poetic, mysterious, yet simple life, as I have grown to see it through the long years with many tribes. Toward that end let us close our eyes for an instant, and in a flash of time span the gulf between today's turmoil and the far away enchanted realm of primitive man. We have entered what is to us a strange land. Man and nature are one and a-tune. All about us are the mysteries of the Infinite." (Clements and Leistner 2010:17) 


\section{The Play}

In the introduction to the special edition of "Theatre Research in Canada" - one dedicated to Marie Clements - Reid Gilbert writes that the playwright is "a complex and fascinating theatre artist: dramatist, actor, and director. Her plays are intellectually provocative and challenging, presenting Aboriginal and feminist issues in a highly 'painterly' style [...]. Mixing western theatrical practice with techniques of Aboriginal storytelling and ritual, Clements interrogates specific historical events [...] and individual memories" (2010:v). The features Gilbert writes about are also reflected in the play titled The Edward Curtis Project, which presents several hours in the life of Angelina, a contemporary journalist involved in issues of indigenous inhabitants in an undefined location in North America. This is a peculiar time for the protagonist, since she is experiencing nervous breakdown, which is clearly associated with her work. Only at the end of the play do we learn that the crisis was caused by the story that Angelina had described for her newspaper. The article was about a man who went out with his three children in the winter seeking a doctor for one of them. Unfortunately, he got drunk and fell asleep on the way, and when he woke up he discovered that his children had frozen to death. It was the vision of bodies of the frozen children and the guidelines of article-writing imposed by the editors of the article that led Angelina to breakdown. The text was supposed to present facts in an emotionless manner and point to the drunkenness and irresponsibility of Amerindians. The protagonist wrote the text according to the guidelines of the newspaper, but she felt deep inner discord with this approach: focusing on 'just facts' allows white recipients to ignore their responsibility for contemporary poverty, the poor housing situation, and violence in indigenous com- munities. At a moment of the strongest agitation, Angelina shouts to her family that she did not write a real story, because she described an Indian father who got drunk and abandoned his children in the snow. When Yiska, her fiancé, remarks: “But that's what he did," she replies:

‘Did he? Or did we drop him a long time ago? I should have written that the father of those children was so young, so poor... living in a house that was so contaminated it should have been torn down... living between cardboard walls with no food, no clean water, no phone, no heat, and the only reason he decided to go out into minus-thirty-eight weather was because one of his kinds was sick... He went out to get help... Do you think it was all his fault? Or maybe we all should own a little piece of it?' (as cited in Clements and Leistner 2010:46)

Angelina herself comes from a mixed family - her mother is an Indian, while her father has Russian roots - and she has dark skin, unlike her sister Clara. The difference in the appearance of the sisters also contributes to the discussion of the attitude of the whites to people of a darker skin color. For her entire life, Angelina carried the non-verbalized feeling that she was in some way worse and less valuable than her sister. Clara shyly disagrees, but Angelina replies: "If we were all sinking in a boat right now... Who do you think would get out first? [...] survival depends on the chance of your skin being white or brown?" (as cited in Clements and Leistner 2010:49). Clara is a popular psychotherapist, but she cannot cope with her sister's problems. Trying to uplift the spirit of Angelina, Clara offers her edition of The North American Indian, which becomes a symbolic intersection of the past and the present. Historical figures appear on stage: Edward S. Curtis, his wife Clara, Alexander Upshaw(the fa- 
vorite interpreter of Curtis), and Princess Angeline. They are visible to all contemporary characters and help the protagonist to regain psychological balance. Edward S. Curtis, called 'The Chief,' becomes another protagonist, alongside Angelina. The playwright presents him as a kind and cordial man of enormous knowledge, skills, and experience. His professional and private experiences, however, intertwine into a rather tragic path, which cost him a nervous breakdown and doubt in the sense of his life. The Chief no longer needs fame and recognition for his work, but, rather, seeks understanding and forgiveness of the mistakes he made as a human being. Angelina finds in him an attentive listener, and his approach to life and work is similar to her own. However, this immaculate character loses much of its sweetness at the time of confrontation with Yiska. The fiancé of Angelina is hostile to Chief from the very beginning due to lies, manipulations and preying on naivety of the photographed people which he committed while documenting the fate of 'the vanishing race.' He wants to turn Curtis out of the apartment and when his request is ignored, he threatens to use force. The Chief begins to threaten him with weapon and screams that he will leave if Yiska puts down the knife. When Yiska denies that he has a knife, Curtis says sneeringly: "Indians always have a knife... Have it in your way... just don't get close to me or, so help me God, I will shoot you" (Clements and Leistner 2010:52). The conversation with Princess Angeline, translated by Alexander Upshaw, is yet another moment when it becomes clear that the Chief, despite all his knowledge of Indian life, is still guided by stereotypes. The negotiations concern taking a photograph, and, of course, settling the form of payment. Hungry Amerindians are pushed to take the risk of capturing their spirits by photography and agreeing to pose, which, in fact, is an act of humiliation. Curtis does not seem to understand this and urges Upshaw to 'reduce' the costs. The scene highlights the role of an interpreter - according to the Chief a "perfectly educated and absolutely uncivilized" man - who tries to carry on this conversation in such a way so that Princess Angeline can get as much as possible and the photographer can be satisfied with the portrait.

The play, sparing with words, is extremely complex in the visual aspect. Photographs, made both by Curtis and Leistner, as well as short films and animations are all projected on stage. The story is accompanied by traditional and contemporary indigenous music as well as recordings from Curtis' wax cylinders and their adaptations. The playwright willingly uses all the achievements of the titular character. As Brenda Vellino (2017) states,

Clements's restaging of Curtis's performance within her play, as well as her projections of photographic and cinematic images on screens surrounding the stage, thus highlights the ways characters and audience members alike must negotiate a complexly mediated world. Such self-reflexive attention to mediation not only heightens a contemporary audience's awareness of the ways in which Indigenous and settler peoples' power relations are scripted and framed, but also reminds us that they are subject to re-negotiation through the mode of rehearsed re-enactment. (pp. 98-99)

\section{The Photographs}

During one of his conversations with Angelina, Curtis tells her about the beginnings of his fascination with photography and mentions the zealous faith that his father instilled in him. Asked by her if he means the belief in God, he answers: "No... just the belief in light... but I suppose the belief in dark- 
ness too. That intense darkness transforms what your naked eye sees into what it could only imagine holding. If light is the basis of photography... maybe darkness is the basis of humanity" (Clements and Leistner 2010:35). This game of light and shadow, good and evil, an objective viewer and an involved participant is largely related to the problem of seeing the life of the indigenous peoples and the ways of documenting it.

The photographs by Rita Leistner are an integral part of The Edward Curtis Project. They were first used in the performance and then published in the book of the same title. As Vellino again explains (2017),

Rita Leistner's photographic contribution to TECP [...] attends to the politics of mediation. In contrast to Curtis, Leistner was self-reflective about the power of her medium: 'How could I photograph Aboriginal Peoples [...] without repeating the appropriations and objectifications of colonial photographers and ethnographers?' [...] As a non-Indigenous artist photographing Indigenous community members, her method was to develop a collaborative practice in which Indigenous subjects were invited to present themselves in a manner that explicitly foregrounds their control of the image-making process. When a Haida youth actor asked to be photographed in both his cultural regalia and his 'street clothes' and then posted these paired images on Facebook, Leistner notes: so began the diptych series that became a central motif [...] a photographic exploration of past and present, traditional and modern, as presented by the subjects themselves. (p. 99)

Leistner and her camera followed Curtis when photographing the modern everyday life of the representatives of the tribes she encountered, as well as their ritual and traditional costumes that they put on in the setting of their choice. This way, she pre- pared dozens of diptychs showing people in modern and traditional costumes. It was a process of photographic exploration of the past and the future; the tradition and the contemporariness revealed by photographed persons. Leistner noticed that she was a 'white' photographer of Indians, just like Curtis, but unlike him, she did not impose any setting on her models, but allowed them to tell their own story in their own way instead. As a representative of the concerned photography school, Leistner always saw her work as a kind of compassionate ethnography - without prejudice, without arranging a photo set, without directing positions of photographed people.

Leistner's work, which the artist herself describes as socially and politically engaged, is based primarily on the direct experience of the surrounding reality. Ocular participation in events allows the creation of original and direct messages that often turn out to be the most valuable to recipients. This is especially true for work related to documenting life of communities which, for various reasons, have found themselves in a new and unusual situation and must now cope with extreme conditions. It is also important what happens to the photos after they are taken: how they will be developed, who will publish them and what their scope will be, as well as how the author of the photo is responsible for it. When commenting on these issues in one of the interviews (2016), the photographer said:

I was drawn to photojournalism because of its power to effect political and social change. So I believe the impulse to be a photojournalist is ethical in itself. If you believe this, then you can justify almost anything you do to advance that end. [...] I think it's unethical to take photojournalistic images and not do anything with them, or just use them as portfolio pieces or for 
entering contests. There has to be some kind of sustained effort to make the photographs serve a purpose. (Leistner and Battleface 2016)

Photography is much more than just taking a picture - there are plenty of details that every professional photographer pays attention to while working, while at the same time trying to create the unique, professional personality, and individual style.

Commenting on the photographs taken as part of TECP, Leistner says: “Each photo, an unknown until it is made, must speak for itself; finally, from a collection of images, a story begins to reveal itself. [...] I hope my photographs create a visual dialogue or bridge between past and present, between legacy of Edward Curtis and the colonial past, and the bright future elucidated by many of the people I met in my travels" (Clements and Leistner 2010:72-73). Photographs in the performance are shown without captions, while in the book only the basic details of the models are revealed. This provided the recipients with an additional possibility for making their own interpretations.

\section{Conclusion}

The perception of events or history is usually shaped and modeled by the medium - e.g. photography (as in the case of the discussed project) - and thus can become the result of a more or less conscious process of 'making the reality less real.' Images provided by various media no longer have a documentary guarantee of being real. And even when the recipients consider them to be 'real,' they are only a representation of some virtual events that can be looked at closely, but not as something unique or different from the rest of the viewed contents. This issue is discussed by, among others, Wolfgang Welsch, who in his book titled Grenzgaenge der Aesthetik notes that the difference between reproducing and simulating the reality is becoming less and less clear and is gradually losing its significance. According to Welsch, the reality is increasingly mediated by the media and the difference between re-creating the reality and simulating it is becoming less and less evident and it loses its importance (Welsch 2005:124). Moreover, the difference mentioned by the author is now more and more difficult to grasp. The relationship between the reality and the story about it is always mediated by knowledge, attitude, ideas, positions, and the medium used to publish the tales. The narrative discourse is present in various approaches within sociology, anthropology, and philosophy(referring, for example, to the identity of an individual, or flu, or a historical experience). As Marianna Michałowska (2012) explains,

[i]n each of them photography plays a different role: as research documentation (in sociology and ethnography), as an expression of experience (in psychology) or as a historical source. There are also... qualitative methodologies inspired by feminism, psychoanalysis or post-colonial thought, leading to the development of a new approach within 'visual methodologies.' An image - used simultaneously as an object of interpretation and as a research tool - cannot go without them in a narrative. (p. 103)

It should also be remembered that a sociologist is also a member of the society in which they acquire certain forms of perception and sensitivity. Although they perceive the social world more clearly in a visual aspect than in other ways (various events, phenomena, or social situations), they also attach greater importance to its visual manifestations (Sztompka 2005:21). 
In her Artist Statementthat precedes the text of the play, Marie Clements writes: "I have no artistic statement. Almost nothing left to say. Everything I saw, or wrote, or did, disbelieved, witnessed and perceived, argued and debated, ate and slept is as altered and layered as any truth or dream of being is - it is all in the play" (Clements and Leistner 2010:5). Rita Leistner clearly points to the important aspect of the work made by Curtis - the one referring directly to the self-awareness of the photographed, described, and recorded tribes: "It was a commonly held view in Curtis's time that the Aboriginal peoples of North America were a 'vanishing race' - and his job was to create a photographic record before it was 'too late.' But what happens when the 'vanishing race' doesn't vanish? What is the impact on a people who are told they are vanishing?" (Clements and Leistner 2010:71). This question was the main inspiration when working

\section{References}

Clements, Marie. 2014. Marie Clements. No Pagination in Return to the Land of the Head Hunters, edited by B. Evans and A. Glass. Seattle: University of Washington Press.

Clements, Marie and Rita Leistner. 2010. The Edward Curtis Project: A Modern Picture Story. Vancouver: Talonbooks.

Dziewit, Jakub and Pisarek Adam. 2016. Ciemnia antropologiczna." Pp. 11-28in Patrzenie i widzenie w kontekstach kulturowych, edited by J. Dziewit, M. Kołodziej, and A. Pisarek. Katowice: Uniwersytet Śląski w Katowicach.

Gilbert, Reid. 2010 “Introduction: Marie Clements.” Theatre Research in Canada 31(2):v-xxvii. on The Edward Curtis Project. As a result, Clements and Leistner have prepared a project that can undoubtedly inspire new attempts at reconciliation and compensation by showing the most problematic points of coexistence, but at the same time suggesting new ways of cultural negotiation between indigenous peoples and settlers. Undoubtedly, this is a difficult task, but the mutual relations between these two groups demand a thorough redefinition. However, there is always an unwavering will to survive and confide in the essence of what makes us humans. As Angelina and Yiska say at the end of the play: "We have survived despite what you can, or cannot, see. [...] We have survived despite what has or hasn't been said. [...] What has or hasn't been done... [...] We have survived across time, across place, to love each other towards a new day" (as cited in Clements and Leistner 2010:66-67).
Huago, Ann. 2016. "Decolonizing Motherhood. Images of Mothering in First Nations Theatre." Theatre History Studies 35:269-284, 377-378.

Jeziorski, Ireneusz. 2011. Wprowadzenie do antropologii i socjologii wizualnej. Bielsko-Biala: ATH.

Leistner, Rita and Battleface. 2016. "Rita Leistner award-winning photojournalist." Retrieved April 2020 (https://wordsandimages.battleface.com/rita-leistner/).

Michałowska, Marianna. 2012. FOTO-TEKSTY zwiazki fotografii z narracja. Poznan: Wydawnictwo Naukowe UAM. 
Moulton, Candy. 2015. "Preserving The Legacy of Edward S. Curtis." Wild West, December 2015, p. 16.

Nanibush, Wanda. 2011. "The Frozen Bodies of Edward S. Curtis." Literary Review of Canada April, pp. 3-8.

Roosevelt, Theodore. 1976. "Foreword." No Pagination in The North American Indian. The Indians of the United States and Alaska, edited by Edward S. Curtis, New York: Johnson Reprint Corporation.
Sztompka, Piotr. 2005. Socjologia wizualna. Fotografia jako metoda badawcza. Warsaw: Wydawnictwo Naukowe PWN.

Vellino, Brenda. 2017. "Restaging Indigenous-Settler Relations: Intercultural Theatre as Redress Rehearsal in Marie Clements's and Rita Leistner's 'The Edward Curtis Project."' Theatre Research in Canada 38(1):92-111.

Welsch, Wolfgang. 2005. Estetyka poza estetyka. Cracow: Universitas.

\title{
Citation
}

Kukiełko-Rogozińska, Kalina. 2020. "Following the Footprints of Edward S. Curtis: A Tale of the Vanishing Race." Przeglad Socjologii Jakościowej 16(2):36-45. Retrieved Month, Year (www.przegladsocjologiijakosciowej.org). DOI: http://dx.doi. org/10.18778/1733-8069.16.2.03

\section{Śladami Edwarda Curtisa. Opowieść o znikającej rasie}

\begin{abstract}
Abstrakt: Kanadyjska dramatopisarka Marie Clements została w 2007 roku poproszona o przygotowanie sztuki teatralnej dotyczącej kulturowej historii Kanady. Clements postanowiła przygotować spektakl o Edwardzie S. Curtisie i jego epickim dziele The North American Indian (1900-1930). Podstawą realizacji tego projektu stały się znane na całym świecie prace Curtisa, który na przełomie XIX i XX wieku zajmował się dokumentowaniem życia znikającej rasy Indian Ameryki Północnej. Do współpracy w opracowaniu graficznej strony sztuki oraz próby odtworzenia drogi, jaką przebył Curtis, uwieczniając sceny z życia rdzennej ludności, Clements zaprosiła kanadyjską fotografkę Ritę Leistner. Artystki odbyły fascynującą podróż śladami Curtisa, rejestrując współczesną obecność First Nations w Stanach Zjednoczonych i Kanadzie. Artykuł, opierając się na projekcie Clements i Leistner, ukazuje grę pomiędzy „odtwarzaniem” prawdziwej rzeczywistości na fotografiach a jej „kreowaniem” przez ich autora. W tekście przedstawione zostały trzy podstawowe wątki: misja i twórczość Edwarda S. Curtisa; sztuka Marie Clements pt. The Edward Curtis Project: A Modern Picture Story oraz zdjęcia Rity Leistner, które były wykorzystane w sztuce, a następnie zostały opublikowane w książce o tym samym tytule. Celem niniejszego tekstu jest przedstawienie projektu kanadyjskich autorek w kontekście socjologii i antropologii wizualnej i ukazanie potencjału fotografii jako środka budowania społecznego dyskursu, tworzenia narracji określonej społeczności. U jego podstaw leży założenie, że ten projekt artystyczny, opierając się na (zarówno biernym, jak i aktywnym) uczestnictwie autorów w codziennym życiu prezentowanej w nim społeczności, staje się źródłem wartościowego materiału badawczego, który może być następnie poddawany interpretacji o charakterze naukowym.
\end{abstract}

Słowa kluczowe: fotografie ludności rdzennej, First Nations, Indianie Ameryki Północnej, znikająca rasa, socjologia wizualna 